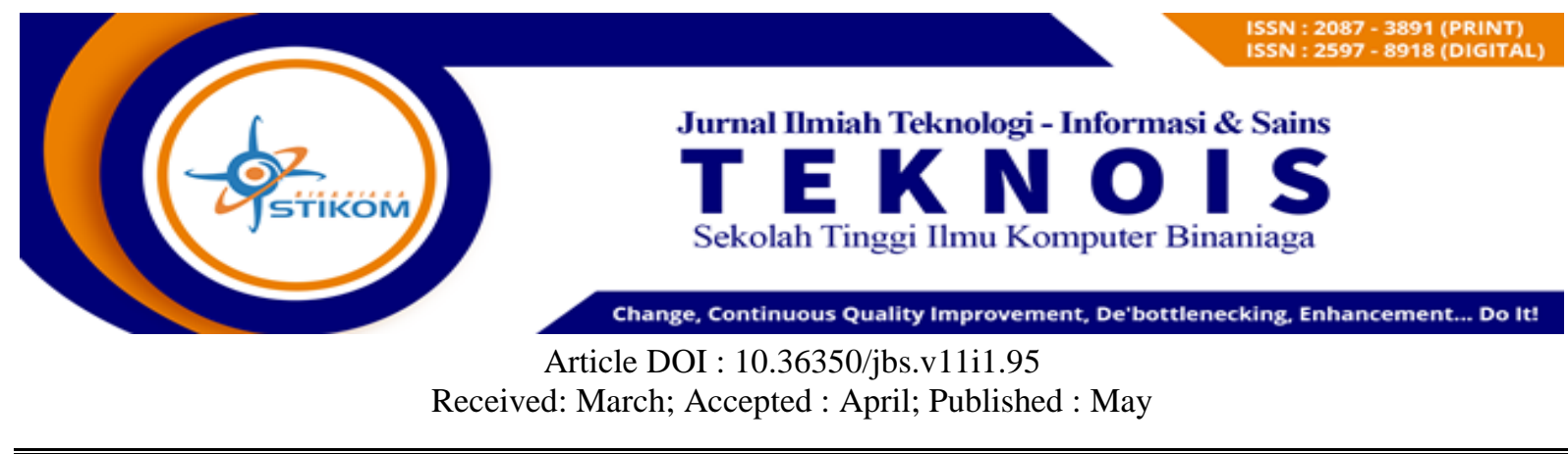

\title{
Penerapan Metode Fuzzy Simple Additive Weighting (SAW) untuk Menentukan Peningkatan Hasil Belajar Siswa
}

\author{
Dedy Mulyadi ${ }^{*}$, Faizal Sachrul ${ }^{2}$ \\ ${ }^{1}$ Sistem Informasi/STIKOM Binaniga \\ Email: dedymulyadi@stikombinaniaga.ac.id \\ ${ }^{2}$ Sistem Informasi/STIKOM Binaniga \\ Email: faizal.sach@gmail.com
}

\begin{abstract}
Student learning outcomes are the results obtained by students after the student has carried out learning and learning activities accompanied by evidence of success that has been achieved by $a$ student by involving cognitive, affective, and psychomotor aspects expressed in the form of symbols, letters, and sentences. One of the wishes of the classroom teacher is to find out which students have increased from the learning and learning outcomes that have been carried out in school, but have difficulty making decisions in determining which students have experienced the best increase in learning outcomes. The Fuzzy Simple Additive Weighting (F-SAW) method is suitable for use as a decision support system to help teachers decide which students with the best improvement in learning outcomes.
\end{abstract}

Keywords: Fuzzy; Fuzzy SAW; Prototype; Learning Outcomes

\section{ABSTRAK}

Hasil belajar siswa adalah suatu hasil yang diperoleh siswa setelah siswa tersebut melakukan kegiatan belajar dan pembelajaran disertai bukti keberhasilan yang telah dicapai oleh seseorang siswa dengan melibatkan aspek kognitif, afektif, maupun psikomotorik yang dinyatakan dalam bentuk simbol, huruf, maupun kalimat. Salah satu keinginan guru kelas adalah mengetahui siswa yang mengalami peningkatan dari hasil belajar dan pembelajaran yang telah dilakukan di sekolah, namun mengalami kesulitan untuk mengambil keputusan dalam menentukan siapa siswa yang mengalami peningkatan hasil belajar terbaik. Metode Fuzzy Simple Additive Weighting (FSAW) layak digunakan sebagai sistem pendukung keputusan untuk membantu guru dalam memutuskan siswa dengan peningkatan hasil belajar terbaik.

Keywords: Fuzzy; Fuzzy SAW; Prototipe; Hasil Belajar.

\section{A. PENDAHULUAN}

1. Latar Belakang

Dalam bidang pendidikan, setiap instansi selalu memperhatikan hasil belajar siswa. Hasil belajar siswa adalah suatu hasil yang diperoleh siswa setelah siswa tersebut melakukan kegiatan belajar dan pembelajaran disertai bukti keberhasilan yang telah dicapai oleh seseorang siswa dengan melibatkan aspek kognitif, afektif, maupun psikomotorik yang dinyatakan dalam bentuk symbol, huruf, maupun kalimat.

Hasil belajar siswa juga dipengaruhi oleh beberapa faktor yaitu faktor internal dan faktor eksternal. Faktor internal merupakan faktor yang berasal dari dalam diri siswa tersebut, terdiri 
Volume 11 Number 1 May 2021 Page. 1-10

Journal Homepage : http://teknois.stikombinaniaga.ac.id/index.php/JBS

DOI Link : http://doi.org/10.36350/jbs.v11i21

atas faktor fisiologis dan psikologis. Sedangkan faktor eksternal adalah faktor yang berasal dari luar diri siswa yang terdiri atas faktor keluarga, sekolah, dan masyarakat. Hasil belajar juga dapat dilihat melalui kegiatan evaluasi yang dilakukan oleh guru yang bertujuan untuk mendapatkan data pembuktian yang akan menunjukkan tingkat kemampuan siswa dalam mencapai tujuan pembelajaran.

Pengambilan keputusan pada dasarnya merupakan pemilihan keputusan atau kebijakan yang didasarkan atas kriteria tertentu. Proses ini meliputi dua alternatif atau lebih, dengan harapan akan menghasilkan sebuah keputusan yang terbaik. Begitu juga dalam memilih siswa yang mengalami peningkatan hasil belajar paling baik diperlukan analisis yang tepat sehingga guru atau wali kelas dapat melakukan pemilihan terhadap siswa di kelas.

\section{Rumusan Masalah}

Guru kelas di Sekolah Dasar Islam Al-Fauzien, Jakarta Selatan, ingin mengetahui siswa yang mengalami peningkatan dari hasil belajar dan pembelajaran yang telah dilakukan di sekolah. Dalam hal ini guru juga mengalami kesulitan untuk mengambil keputusan dalam menentukan siapa siswa yang mengalami peningkatan hasil belajar paling baik.

\section{Tujuan}

Untuk menghindari subjektifitas keputusan yang dihasilkan, diperlukan sistem pendukung keputusan yang dapat membantu pihak sekolah dalam memutuskan siswa mana yang terpilih. Metode yang digunakan dalam menentukan siswa yang mengalami peningkatan hasil belajar paling baik pada Sekolah Dasar Islam Al-Fauzien adalah metode Fuzzy Simple Additive Weighting (F-SAW).

\section{Tinjauan Pustaka}

\section{a. Sistem Pendukung Keputusan}

Sistem Pendukung Keputusan merupakan bagian dari sistem informasi berbasis komputer termasuk sistem manajemen berbasis pengetahuan yang digunakan untuk mendukung pengambilan keputusan dalam suatu organisasi atau perusahaan. Bisa juga dianggap sebagai sistem komputer yang mengolah data menjadi informasi untuk pengambilan keputusan masalah spesifik semi-tersutruktur. Menurut Moore dan Chang (1980), sistem pendukung keputusan dapat digambarkan sebagai sistem yang mampu mendukung analisis adhoc data dan pemodelan keputusan, berorientasi keputusan, orientasi perencanaan masa depan dan dapat digunakan pada waktu yang tidak biasa.

Tujuan dari sistem pendukung keputusan itu sendiri adalah melayani manajemen operasi, tingkat perencanaan organisasi, meningkatkan efektifitas dalam pengambilan keputusan dan membantu orang membuat keputusan tentang masalah yang mungkin berubah dengan cepat dan tidak mudah diselesaikan.

Menurut Herbert A. Simon (Kadarsah, 2002), tahap-tahap yang harus dilalui dalam proses pengambilan keputusan sebagai berikut:

1) Tahap Pemahaman. Tahap ini merupakan proses penelusuran dan pendeteksian dari lingkup problematika serta proses pengenalan masalah. Data masukan diperoleh, diproses dan diuji dalam rangka mengidentifikasikan masalah.

2) Tahap Perancangan. Tahap ini merupakan proses pengembangan dan pencarian alternatif tindakan / solusi yang dapat diambil, merupakan representasi kejadian nyata yang disederhanakan, sehingga diperlukan proses validasi dan vertifikasi untuk mengetahui keakuratan model dalam meneliti masalah yang ada.

3) Tahap Pemilihan. Tahap ini dilakukan pemilihan terhadap berbagai alternatif solusi yang dimunculkan pada tahap perencanaan agar ditentukan dengan memperhatikan kriteria-kriteria berdasarkan tujuan yang akan dicapai.

4) Tahap Impelementasi. Tahap ini dilakukan penerapan terhadap rancangan sistem yang telah dibuat pada tahap perancanaan serta pelaksanaan alternatif tindakan yang telah dipilih pada tahap pemilihan. 


\section{b. Logika Fuzzy}

Konsep tentang logika fuzzy diperkenalkan oleh Prof. Lotfi Astor Zadeh pada tahun 1962. Logika fuzzy adalah metodologi sistem kontrol pemecahan masalah, yang cocok untuk diimplementasikan pada sistem, mulai dari sistem yang sederhana, sistem kecil, embedded system, jaringan PC, multi-channel atau workstation berbasis akuisisi data, dan sistem kontrol. Metodologi ini dapat diterapkan pada perangkat keras, perangkat lunak, atau kombinasi keduanya. Dalam logika klasik dinyatakan bahwa segala sesuatu bersifat biner, yang artinya adalah hanya mempunyai dua kemungkinan, "Ya" atau "Tidak", "Benar" atau "Salah", "Baik" atau "Buruk", dan lain-lain. Oleh karena itu, semua ini dapat mempunyai nilai keanggotaan 0 atau 1. Akan tetapi, dalam logika fuzzy memungkinkan nilai keanggotaan berada di antara 0 dan 1 . Artinya, bisa saja suatu keadaan mempunyai dua nilai "Ya" dan "Tidak", "Benar" dan "Salah", "Baik" dan "Buruk" secara bersamaan, namun besar nilainya tergantung pada bobot keanggotaan yang dimilikinya. Logika fuzzy dapat digunakan di berbagai bidang, seperti sistem diagnosa penyakit (dalam bidang kedokteran); pemodelan sistem pemasaran, riset operasi (dalam bidang ekonomi); kendali kualitas air, prediksi adanya gempa bumi, klasifikasi dan pencocokan pola.

\section{c. Simple Additive Weighting}

Salah satu metode penyelesaian masalah adalah dengan menggunakan metode Simple Additive Weighting (SAW). Metode Simple Additive Weighting (SAW) menurut Kusumadewi (2006), sering juga dikenal dengan istilah metode penjumlahan terbobot. Konsep dasar Simple Additive Weighting (SAW) adalah mencari penjumlahan terbobot dari kinerja setiap alternatif pada semua atribut. Metode Simple Additive Weighting (SAW) merupakan metode yang banyak digunakan dalam pengambilan keputusan yan memiliki banyak atribut. Metode Simple Additive Weighting (SAW) membutuhkan proses normalisasi matriks keputusan $(\mathrm{X})$ ke suatu skala yang dapat diperbandingkan dengan semua rating alternatif yang ada.

Formula untuk melakukan normalisasi tersebut adalah sebagai berikut:

$$
r i j=\left\{\begin{array}{lr}
\frac{X i j}{M a x x i j} & j i k a j \text { attribut keuntungan (benefit) } \\
\frac{M i n X i j}{X i j} & \text { jikaj attribut biaya (cost) }
\end{array}\right.
$$

Keterangan:

$\begin{array}{lll}\operatorname{Max} \mathrm{X}_{\mathrm{ij}} & = & \text { Nilai terbesar dari setiap kriteria } \mathrm{i} . \\ \operatorname{Min} \mathrm{X}_{\mathrm{ij}} & = & \text { Nilai terkecil dari setiap kriteria i. } \\ \mathrm{X}_{\mathrm{ij}} & = & \text { Nilai atribut yang dimiliki dari setiap kriteria. } \\ \text { Benefit } & = & \text { Jika nilai terbesar adalah yang terbaik. } \\ \text { Cost } & = & \text { Jika nilai terkecil adalah yang terbaik. }\end{array}$

Dimana $r_{i j}$ adalah rating kinerja ternormalisasi dari alternatif $A_{i}$ pada atribut $C_{i j} i=1,2, \ldots$, n. Nilai prefrensi untuk setiap alternatif $(\mathrm{Vi})$ diberikan sebagai:

$$
\mathrm{v}_{\mathrm{i}}=\sum_{\mathrm{I}=1}^{n} \mathrm{w}_{\mathrm{j}} \mathrm{r}_{\mathrm{ij}}
$$

Keterangan:

$\mathrm{V}_{\mathrm{i}}=\quad$ Peringkat untuk setiap alternatif.

$\mathrm{W}_{\mathrm{j}}=\quad$ Nilai bobot peringkat (dari setiap kriteria).

$\mathrm{r}_{\mathrm{ij}}=\quad$ Nilai rating kinerja ternormalisasi.

Nilai Vi yang lebih besar mengidentifikasikan bahwa alternatif Ai lebih terpilih. 


\section{B. METODE}

\section{Model Yang Di Usulkan}

Metode yang digunakan dalam penelitian ini adalah Research and Development (RnD). Penelitian dan pengembangan atau research and development $(R n D)$ merupakan suatu proses atau langkah-langkah untuk mengembangkan suatu produk baru atau menyempurnakan produk yang sudah ada dan dapat dipertanggungjawabkan. Produk tersebut dapat berupa perangkat keras (hardware) ataupun perangkat lunak (software).

Menurut Sugiyono (2009) menyatakan bahwa langkah-langkah dalam penelitian Research and Development ( $\mathrm{RnD})$ terdiri atas 10 langkah berikut ini, yaitu potensi dan masalah, pengumpulan data, desain produk, validasi desain, revisi desain, ujicoba produk, revisi produk, uji coba pemakaian, revisi produk dan produksi masal. Secara skematik langkahlangkah tersebut dapat ditujukan seperti pada gambar 1.

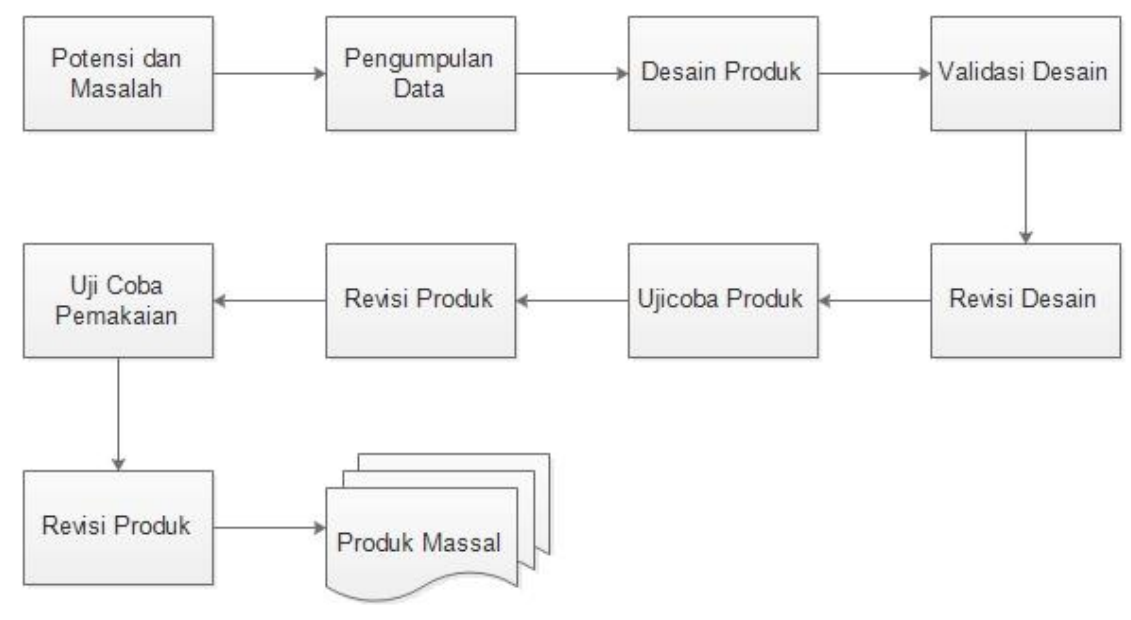

Gambar 1. Langkah-langkah RnD

\section{Responden}

Responden yang digunakan dalam penelitian ini adalah 5 (lima) orang pengguna dari kalangan guru, dan 4 (empat) orang tenaga ahli / ahli sistem informasi dari kalangan tenaga pendidik yang relevan.

\section{Teknik Pengumpulan Data}

Pengumpulan data penelitian dilakukan melalui wawancara, penyebaran kuesioner, dan studi literatur yang relevan.

\section{Teknik Analisa Data}

Dalam penelitian ini, metode analisis data menggunakan persentase kelayakan. Adapun rumus yang digunakan adalah sebagai berikut:

$$
\text { Persentase kelayakan }(\%)=\frac{\text { skor yang diobservasi }}{\text { skor yang diharapkan }} X 100 \%
$$

Hasil persentase digunakan untuk memberikan jawaban atas kelayakan dari aspek-aspek yang diteliti. Menurut Arikunto (2009: 44) pembagian kategori kelayakan ada lima. Skala ini memperhatikan rentang dari bilangan persentase. Nilai maksimal yang diharapkan adalah $100 \%$ dan minimum 0\%. Pembagian rentang kategori kelayakan menurut arikunto (2009: 44) dapat dilihat pada Table 1 berikut:

Tabel 1. Kategori Kelayakan

\begin{tabular}{|l|l|}
\hline Persentase Pencapaian & Interpretasi \\
\hline$<21 \%$ & Sangat Tidak Layak \\
\hline $21 \%-40 \%$ & Tidak Layak \\
\hline $41 \%-60 \%$ & Cukup layak \\
\hline $61 \%-80 \%$ & Layak \\
\hline $81 \%-100 \%$ & Sangat Layak \\
\hline
\end{tabular}

(Sumber : Arikunto, 2009, p.44) 


\section{HASIL DAN PEMBAHASAN}

\section{HASIL}

Hasil penelitian yang telah dilakukan di Sekolah Dasar Islam Al-Fauzien, melalui proses wawancara terhadap guru yang mengajar di kelas sebagai proses analisis kebutuhan dari perangkat lunak yang akan dibuat, selain itu bertujuan untuk mengetahui proses penentuan siswa dengan peningkatan hasil belajar paling baik di kelas yang akan diterapkan pada suatu model perankingan yaitu model fuzzy multi attribute decision making (FMADM) metode simple additive Weighting (SAW).

Kandidat siswa dengan peningkatan hasil belajar paling baik ialah siswa yang berada di kelas tersebut. Berikut data peningkatan nilai yang terdapat pada siswa kelas 2 di Sekolah Dasar Islam Al-Fauzien.

Tabel 2. Nilai Siswa

\begin{tabular}{|c|c|c|c|c|c|c|c|c|c|c|}
\hline \multirow{3}{*}{ NO } & \multirow{3}{*}{ NAMA } & \multicolumn{9}{|c|}{ PENINGKATAN NILAI } \\
\hline & & \multicolumn{3}{|c|}{ MATH } & \multicolumn{3}{|c|}{ SCIENCE } & \multicolumn{3}{|c|}{ ENGLISH } \\
\hline & & UTS & UAS & NH & UTS & UAS & NH & UTS & UAS & NH \\
\hline 1 & Althaira Kyosa Azalia Harahap & 9 & 0 & 2 & -7 & -10 & 2 & 18 & 11 & 1 \\
\hline 2 & Aria Lorena Stophira & -5 & 16 & 11 & 1 & -9 & 2 & 17 & 7 & 2 \\
\hline 3 & Athief Bagas Priaditomo & 7 & 5 & 1 & -3 & 0 & -1 & 0 & -12 & -3 \\
\hline 4 & Dzaki Ahmad Hakim & -8 & 17 & -3 & -4 & 2 & -1 & -3 & -5 & -4 \\
\hline 5 & Fatima Kizavara Hamdani & 4 & 16 & 4 & 0 & -6 & 1 & -4 & -1 & 0 \\
\hline 6 & Freya Azarenka Ghaniya Selvan & -2 & 4 & 0 & -6 & 1 & -2 & 0 & -2 & 1 \\
\hline 7 & Jasmine Ath Thahirah Lintang & 5 & -2 & 3 & 2 & -3 & -1 & 12 & 12 & -3 \\
\hline 8 & Kimiqoyumi Alesia Tamin & 2 & -2 & 3 & 12 & 9 & 1 & -4 & -8 & -3 \\
\hline 9 & Lionel Athallah Ramadhan & 2 & -7 & -2 & -1 & 3 & -3 & 0 & -3 & 0 \\
\hline 10 & Marouane Sami Kheidira Irawan & 0 & -7 & 5 & 2 & 6 & -4 & -5 & 5 & -2 \\
\hline 11 & Mirzanov Al Aiman Suryana & -12 & -1 & 8 & 12 & -1 & 2 & 0 & 0 & -2 \\
\hline 12 & Muhammad Gibran Ramadhan & 3 & 0 & 2 & 0 & 0 & -3 & 0 & -2 & -1 \\
\hline 13 & Naila Nawfa Assegaf & -11 & 20 & 0 & -8 & 3 & 1 & 12 & -11 & -3 \\
\hline 14 & Prasada Sahyadamar & 10 & 1 & 6 & 2 & 5 & -3 & 18 & -8 & -3 \\
\hline 15 & Quinn Shannia Latisha & 8 & -5 & 6 & 2 & 3 & -1 & -8 & -5 & -1 \\
\hline 16 & Rayhan Arkananta Prasetyo & 0 & -2 & 2 & 1 & 3 & 0 & 0 & 0 & 3 \\
\hline 17 & Safira Syifa Nasyitah & 3 & 2 & 4 & 8 & 7 & 1 & 14 & -15 & 0 \\
\hline 18 & Sahla Alifa Azka Zain & -8 & -4 & 1 & -2 & 2 & -1 & -5 & -3 & 0 \\
\hline 19 & Sultan Rakha Khazindar & -22 & 10 & 2 & 9 & 16 & -1 & 11 & -3 & 3 \\
\hline 20 & Syifa Khalisha Azka & 21 & 1 & 7 & -6 & 2 & -3 & 8 & 1 & -1 \\
\hline 21 & Zafira Denaya Maritza & 6 & -7 & 2 & 11 & 12 & 0 & 15 & -3 & 1 \\
\hline
\end{tabular}

\section{PEMBAHASAN}

\section{a. Penentuan Bobot Kriteria dan Alternatif}

Salah satu proses penerapan metode Fuzzy Simple Additive Weighting ( F-SAW) adalah menentukan bobot kriteria dan alternatif. Langkah-langkahnya sebagai berikut.

1) Kriteria

Merupakan tahapan dalam menentukan ukuran yang menjadi dasar penilaian dan rekomendasi dalam menentukan siswa dengan peningkatan nilai paling baik. Kriteria tersebut diantaranya:

a) Peningkatan Nilai Ujian Akhir Semester

b) Peningkatan Nilai Ujian Tengah Semester

c) Peningkatan Nilai Rata-rata Nilai Ulangan Harian

Dari masing-masing kriteria tersebut, maka dibuat suatu variable-variabelnya. Dimana dari suatu variable tersebut akan diubah menjadi bilangan fuzzy. Berikut adalah bobot bilangan fuzzy:
a) Sangat baik (SB)
$=1$
b) Baik (B)
c) $\operatorname{Cukup}(\mathrm{C})$
$=0,75$
$=0,5$
d) Kurang (K)
$=0,25$
e) Sangat Kurang (SK)
$=0$ 
Volume 11 Number 1 May 2021 Page. 1-10

Journal Homepage : http://teknois.stikombinaniaga.ac.id/index.php/JBS

DOI Link : http://doi.org/10.36350/jbs.v11i21

2) Bobot Kriteria

Dari Kriteria-kriteria yang dibuat, masing masing diberi bobot dari setiap kriteria sebagai berikut:

Tabel 3. Bobot Setiap Kriteria

\begin{tabular}{|l|l|c|}
\hline \multicolumn{2}{|c|}{ Kriteria } & Bobot \\
\hline $\mathrm{C} 1=$ & Peningkatan Nilai Ujian Tengah Semester & $35 \%$ \\
\hline $\mathrm{C} 2=$ & Peningkatan Nilai Ujian Akhir Semester & $40 \%$ \\
\hline $\mathrm{C} 3=$ & Peningkatan Nilai Rata-rata Nilai Ulangan Harian & $25 \%$ \\
\hline
\end{tabular}

C1-C3 adalah nama kriteria yang digunakan lalu diberikan nilai bobot dari setiap kriteria untuk menentukan hasil akhir penjumlahan yang akan terpilih dari beberapa alternative

3) Bobot peringkat kriteria

Variablel Nilai dikonversikan dengan bilangan fuzzy di bawah ini:

Tabel 4. Bobot Peningkatan Nilai Ujian Tengah Semester

\begin{tabular}{|c|c|c|}
\hline Peningkatan Nilai Ujian Tengah Semester & Keterangan & Bobot \\
\hline$>11$ & Sangat Baik & 1 \\
\hline $6-10$ & Baik & 0,75 \\
\hline $1-5$ & Cukup & 0,5 \\
\hline 0 & Kurang & 0,25 \\
\hline$<0$ & Sangat kurang & 0 \\
\hline
\end{tabular}

Variabel kriteria nilai Peningkatan Nilai Ujian Tengah Semester yang telah dikonversikan menjadi bilangan fuzzy dapat dilihat seperti pada tabel 4 .

Variabel kriteria nilai Peningkatan Nilai Ujian Akhir Semester yang telah dikonversikan menjadi bilangan fuzzy dapat dilihat seperti pada tabel 4 .

Variabel kriteria nilai Peningkatan Nilai Rata-Rata Nilai Harian yang telah dikonversikan menjadi bilangan fuzzy dapat dilihat seperti pada tabel 4 .

\section{b. Analisis Penerapan Fuzzy Simple Additive Weighting (F-SAW)}

1) Definisi Masalah dan Solusi

Permasalahan dalam penelitian ini adalah penentuan siswa dengan peningkatan hasil belajar paling baik di kelas di Sekolah Dasar Islam Al-Fauzien dengan kriteria peningkatan nilai ujian akhir semester, peningkatan nilai ujian tengah semester dan peningkatan rata-rata nilai harian. Solusi yang diharapkan muncul adalah hasil siswa dengan peningkatan hasil belajar paling baik berdasarkan kriteria tersebut. Dimana ada 21 alternatif yaitu para siswa yang terdapat pada kelas tersebut.

2) Dekomposisi Masalah

Dalam hal ini disusun pembentukan hirarki untuk menyelesaikan masalah. Ada 3 (tiga) hirarki yang dibuat yaitu:

a) Hierarki pertama (penentuan Goal). Goal yang ingin dicapai adalah siswa dengan peningkatan hasil belajar paling baik.

b) Hierarki kedua (penentuan kriteria). Kriteria yang digunakan sebagai pembanding adalah peningkatan nilai ujian akhir semester, peningkatan nilai ujian tengah semester dan peningkatan rata-rata nilai harian.

c) Hierarki ketiga (penentuan alternatif). Alternatif yang dilibatkan dalam penelitian ini ada 21 siswa yang terdapat di kelas yaitu Althaira Kyosa Azalia Harahap, Aria Lorena Stophira, Athief Bagas Priaditomo, Dzaki Ahmad Hakim, Fatima Kizavara Hamdani, Freya Azarenka Ghaniya Selvan, Jasmine Ath Thahirah Lintang, Kimiqoyumi Alesia Tamin, Lionel Athallah Ramadhan, Marouane Sami Kheidira Irawan, Mirzanov Al Aiman Suryana, Muhammad Gibran Ramadhan, Naila Nawfa Assegaf, Prasada Sahyadamar, Quinn Shannia Latisha, Rayhan Arkananta Prasetyo, Safira Syifa Nasyitah, Sahla Alifa Azka Zain, Sultan Rakha Khazindar, Syifa Khalisha Azka, Zafira Denaya Maritza.

3) Membuat Struktur Hierarki

Struktur hierarki dapat dilihat pada gambar 2 . 


\section{c. Analisis Perhitungan dengan Metode Fuzzy Simple Additive Weighting (F-SAW)}

1) Pengumpulan Data Siswa Kelas 2

Kandidat siswa dengan peningkatan hasil belajar paling baik ialah siswa yang berada di kelas tersebut. Berikut data peningkatan nilai yang terdapat pada siswa kelas 2 di Sekolah Dasar Islam Al-Fauzien (data dapat dilihat pada tabel 2).

Dari data pada tabel 2, selanjutnya menghitung rata-rata untuk peningkatan nilai ujian akhir semester, peningkatan nilai ujian tengah semester dan peningkatan rata-rata nilai harian. Berikut datanya:

Tabel 5. Tabel Rata-Rata Peningkatan Nilai Siswa

\begin{tabular}{|c|l|c|c|c|}
\hline \multirow{2}{*}{ NO } & & \multicolumn{3}{c|}{ RATA-RATA } \\
& & \multicolumn{2}{c}{ PENINGKATAN NILAI } \\
\cline { 3 - 5 } & & UTS & UAS & NH \\
\hline 1 & Althaira Kyosa Azalia Harahap & 7 & 1 & 2 \\
\hline 2 & Aria Lorena Stophira & 5 & 5 & 6 \\
\hline 3 & Athief Bagas Priaditomo & 2 & -2 & 0 \\
\hline 4 & Dzaki Ahmad Hakim & -5 & 5 & -2 \\
\hline 5 & Fatima Kizavara Hamdani & 1 & 3 & 2 \\
\hline 6 & Freya Azarenka Ghaniya Selvan & -2 & 1 & 0 \\
\hline 7 & Jasmine Ath Thahirah Lintang & 7 & 3 & 0 \\
\hline 8 & Kimiqoyumi Alesia Tamin & 4 & 0 & 1 \\
\hline 9 & Lionel Athallah Ramadhan & 1 & -2 & -1 \\
\hline 10 & Marouane Sami Kheidira Irawan & -1 & 2 & 0 \\
\hline 11 & Mirzanov Al Aiman Suryana & 0 & -1 & 3 \\
\hline 12 & Muhammad Gibran Ramadhan & 1 & 0 & 0 \\
\hline 13 & Naila Nawfa Assegaf & -2 & 4 & 0 \\
\hline 14 & Prasada Sahyadamar & 11 & 0 & 1 \\
\hline 15 & Quinn Shannia Latisha & 1 & -2 & 2 \\
\hline 16 & Rayhan Arkananta Prasetyo & 0 & 1 & 2 \\
\hline 17 & Safira Syifa Nasyitah & 9 & -2 & 2 \\
\hline 18 & Sahla Alifa Azka Zain & -4 & -1 & 0 \\
\hline 19 & Sultan Rakha Khazindar & 0 & 8 & 2 \\
\hline 20 & Syifa Khalisha Azka & 8 & 1 & 2 \\
\hline 21 & Zafira Denaya Maritza & 11 & 1 & 2 \\
\hline
\end{tabular}

2) Menentukan alternative dan kriteria

Setelah mendapatkan data yang dibutuhkan, kemudian disusun kecocokan tiap alternative pada setiap kriteria yang dikonversikan ke dalam bilangan fuzzy.

Tabel 6. Tabel Alternatif dan Kriteria

\begin{tabular}{|c|c|c|c|}
\hline \multirow{2}{*}{ ALTERNATIF } & \multicolumn{3}{|c|}{ KRITERIA } \\
\cline { 2 - 4 } & C1 & C2 & C3 \\
\hline A1 & 0,75 & 0,5 & 0,5 \\
\hline A2 & 0,5 & 0,5 & 0,5 \\
\hline A3 & 0,5 & 0 & 0 \\
\hline A4 & 0 & 0,5 & 0 \\
\hline A5 & 0,5 & 0,5 & 0,5 \\
\hline A6 & 0 & 0,5 & 0,25 \\
\hline A7 & 0,75 & 0,5 & 0 \\
\hline A8 & 0,5 & 0 & 0,5 \\
\hline A9 & 0,5 & 0 & 0 \\
\hline A10 & 0 & 0,5 & 0,25 \\
\hline A11 & 0,25 & 0 & 0,5 \\
\hline A12 & 0,5 & 0 & 0 \\
\hline A13 & 0 & 0,5 & 0 \\
\hline A14 & 1 & 0 & 0,5 \\
\hline A15 & 0,5 & 0 & 0,5 \\
\hline A16 & 0,25 & 0,25 & 0,5 \\
\hline A17 & 0,75 & 0 & 0,5 \\
\hline
\end{tabular}


Volume 11 Number 1 May 2021 Page. 1-10 Journal Homepage : http://teknois.stikombinaniaga.ac.id/index.php/JBS DOI Link : http://doi.org/10.36350/jbs.v11i21

\begin{tabular}{|c|c|c|c|} 
A18 & 0 & 0 & 0,25 \\
\hline A19 & 0,25 & 0,75 & 0,5 \\
\hline A20 & 0,75 & 0,5 & 0,5 \\
\hline A21 & 1 & 0,5 & 0,5 \\
\hline
\end{tabular}

Setelah mendapatkan matrix ternormalisasi $(\mathrm{R})$, selanjutnya mengalikan matrix ternormalisasi $(\mathrm{R})$ dengan nilai bobot $(\mathrm{W})$ untuk menentukan nilai preverensi untuk setiap alternative (Vi). Nilai Vi yang lebih besar mengindikasikan bahwa alternative yang terpilih.

\begin{tabular}{|c|c|c|c|}
\hline $\mathrm{V} 1=$ & $(0,75)(0,35)+(0,67)(0,4)+(1)(0,25)$ & $=$ & 0,78 \\
\hline $\mathrm{V} 2=$ & $(0.5)(0.35)+(0.67)(0.4)+(1)(0.25)$ & $=$ & 0,69 \\
\hline $\mathrm{V} 3=$ & $(0.5)(0.35)+(0)(0.4)+(0)(0.25)$ & $=$ & 0,18 \\
\hline $\mathrm{V} 4=$ & $(0)(0.35)+(0.67)(0.4)+(0)(0.25)$ & $=$ & 0,27 \\
\hline $\mathrm{V} 5=$ & $(0.5)(0.35)+(0.67)(0.4)+(1)(0.25)$ & $=$ & 0,69 \\
\hline $\mathrm{V} 6=$ & $(0)(0.35)+(0.67)(0.4)+(0.5)(0.25)$ & $=$ & 0,39 \\
\hline $\mathrm{V} 7=$ & $(0.75)(0.35)+(0.67)(0.4)+(0)(0.25)$ & $=$ & 0,53 \\
\hline $\mathrm{V} 8=$ & $(0.5)(0.35)+(0)(0.4)+(1)(0.25)$ & $=$ & 0,43 \\
\hline $\mathrm{V} 9=$ & $(0.5)(0.35)+(0)(0.4)+(0)(0.25)$ & $=$ & 0,18 \\
\hline $\mathrm{V} 10=$ & $(0)(0.35)+(0.67)(0.4)+(0.5)(0.25)$ & $=$ & 0,39 \\
\hline $\mathrm{V} 11=$ & $(0.25)(0.35)+(0)(0.4)+(1)(0.25)$ & $=$ & 0,34 \\
\hline $\mathrm{V} 12=$ & $(0.5)(0.35)+(0)(0.4)+(0)(0.25)$ & $=$ & 0,18 \\
\hline $\mathrm{V} 13=$ & $(0)(0.35)+(0.67)(0.4)+(0)(0.25)$ & $=$ & 0,27 \\
\hline V14= & $(1)(0.35)+(0)(0.4)+(1)(0.25)$ & $=$ & 0,60 \\
\hline $\mathrm{V} 15=$ & $(0.5)(0.35)+(0)(0.4)+(1)(0.25)$ & $=$ & 0,43 \\
\hline V16= & $(0.25)(0.35)+(0.33)(0.4)+(1)(0.25)$ & $=$ & 0,47 \\
\hline V17= & $(0.75)(0.35)+(0)(0.4)+(1)(0.25)$ & $=$ & 0,51 \\
\hline $\mathrm{V} 18=$ & $(0)(0.35)+(0)(0.4)+(0.5)(0.25)$ & $=$ & 0,13 \\
\hline $\mathrm{V} 19=$ & $(0.25)(0.35)+(1)(0.4)+(1)(0.25)$ & $=$ & 0,74 \\
\hline $\mathrm{V} 20=$ & $(0.75)(0.35)+(0.67)(0.4)+(1)(0.25)$ & $=$ & 0,78 \\
\hline$v 21=$ & $(1)(0.35)+(0.67)(0.4)+(1)(0.25)$ & $=$ & 0,87 \\
\hline
\end{tabular}

Berdasarkan hasil nilai preverensi, berikut 5 alternatif yang mendapatkan nilai tertinggi.

Tabel 7. Tabel alternative dengan hasil tertinggi

\begin{tabular}{|c|c|}
\hline Alternatif & Nilai \\
\hline V21 & 0,87 \\
\hline V1 & 0,78 \\
\hline V20 & 0,78 \\
\hline V19 & 0,74 \\
\hline V2 & 0,69 \\
\hline
\end{tabular}

Siswa yang mengalami peningkatan hasil belajar paling baik berdasarkan nilai skor yang lebih tinggi dari yang lain. Terlihat dari tabel diatas V21 terpilih menjadi yang terbaik karena skornya lebih tinggi dari yang lain. Dengan kata lain, Zafira Denaya Maritza terpilih sebagai siswa yang mengalami peningkatan hasil belajar paling baik di kelas.

\section{d. Hasil Analisis Kelayakan Sistem}

1) Hasil Analisis Kelayakan Menurut Ahli Sistem 
Volume 11 Number 1 May 2021 Page. 1-10

Journal Homepage : http://teknois.stikombinaniaga.ac.id/index.php/JBS

DOI Link : http://doi.org/10.36350/jbs.v11i21

Data yang diperoleh melalui instrumen penelitian kepada ahli sistem dengan menggunakan Skala Guttman. Skala Guttman adalah skala pengukuran yang membutuhkan jawaban tegas dari respondennya. Seperti jawaban "Ya/Valid" atau "Tidak/Tidak Valid". Jawaban tersebut diajukan untuk mendapatkan jawaban yang tegas oleh peneliti terkait permasalahan yang ditanyakan. Untuk kebutuhan analisis, data dibutuhkan pemberian skor kepada jawaban tersebut. Skor yang digunakan untuk jawaban positif (Valid) diberi skor 1 dan skor jawaban negatif (Tidak Valid) diberi skor 0. Hasil persentase digunakan sebagai jawaban atas kelayakan dari aspekaspek yang diteliti. Diperoleh total jawaban valid yaitu 50 dan total jawaban valid yang diharapkan yaitu 50. Maka dapat dicari persentase kelayakan sebagai berikut:

$$
\begin{aligned}
& \text { Persentase Kelayakan }(\%)=\frac{\text { Skor yang diobservasi }}{\text { Skor yang diharapkan }} \times 100 \% \\
& \text { Persentase Kelayakan }(\%)=\frac{50}{50} \times 100 \% \\
& \text { Persentase Kelayakan }(\%)=100 \%
\end{aligned}
$$

Persentase kelayakan yang didapat sebesar 100\%, maka dapat dikategorikan "Sangat Layak".

2) Hasil Analisis Kelayakan Menurut Pengguna

Total skor dari hasil pengisian kuesioner secara Overall dari 5 responden adalah 526. Skor diharapkan adalah nilai skala range tertinggi dikali jumlah pertanyaan dikali jumlah responden. Maka skor yang diharapkan $=(7) \times(16) \times(5)=560$

$$
\begin{aligned}
& \text { Persentase Kelayakan }(\%)=\frac{\text { Skor yang diobservasi }}{\text { Skor yang diharapkan }} \times 100 \% \\
& \text { Persentase Kelayakan }(\%)=\frac{104+108+106+97+111}{560} \times 100 \% \\
& \text { Persentase Kelayakan }(\%)=\frac{526}{560} \times 100 \% \\
& \text { Persentase Kelayakan }(\%)=93.9 \%
\end{aligned}
$$

Persentase kelayakan yang didapat sebesar 93.9\% maka dapat diinterprestasi yang "Sangat Layak".

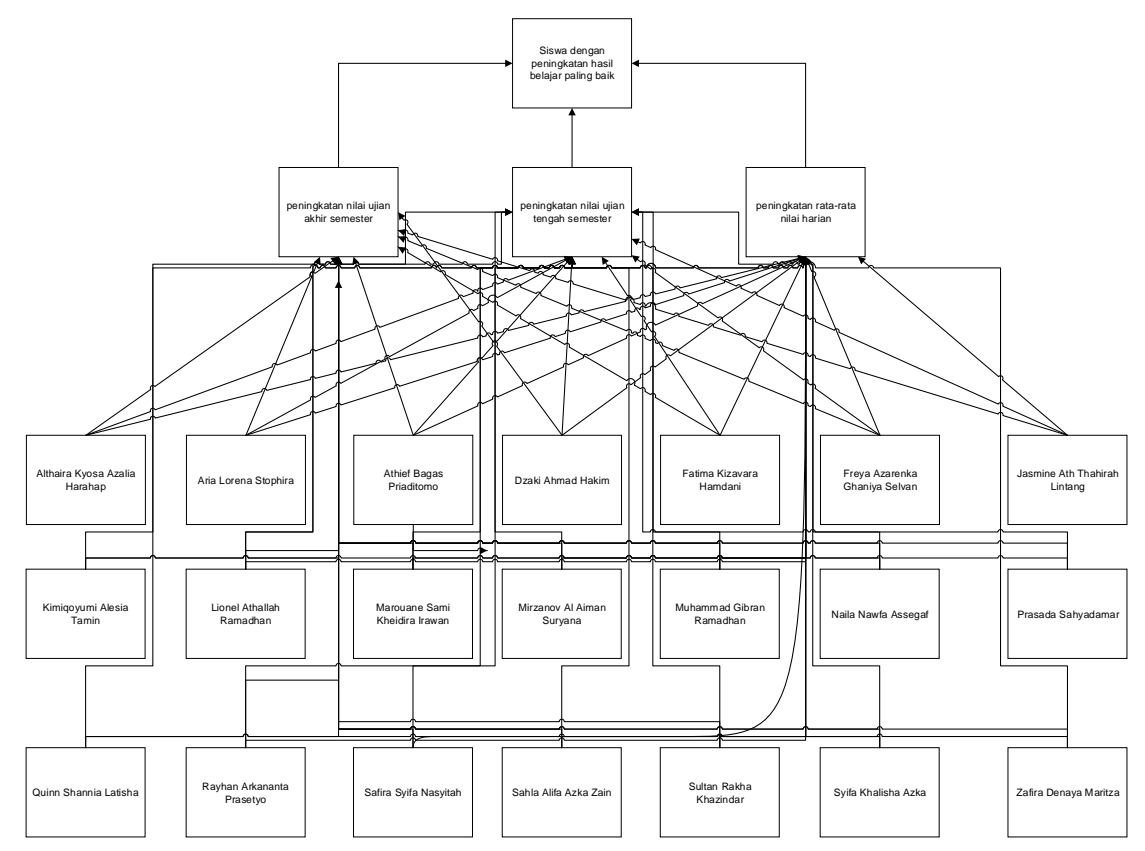

Gambar 2. Struktur hierarki penentuan Siswa dengan peningkatan hasil belajar palling baik 
Volume 11 Number 1 May 2021 Page. 1-10

Journal Homepage : http://teknois.stikombinaniaga.ac.id/index.php/JBS

DOI Link : http://doi.org/10.36350/jbs.v11i21

\section{KESIMPULAN}

Berdasarkan hasil penelitian yang telah dilakukan penulis di Sekolah Dasar Islam Al-Fauzien, maka peneliti dapat mengambil kesimpulan, sebagai berikut:

1. Dibangunnya sebuah system pendukung keputusan untuk membantu pemilihan siswa dengan peningkatan hasil belajar paling baik di kelas, maka dibutuhkan kriteria-kriteria yang telah ditentukan, yaitu peningkatan nilai Ujian Akhir Semester, peningkatan nilai Ujian Tengah Semester dan peningkatan rata-rata nilai ulangan harian.

2. Metode Simple Additive Weighting (SAW) sangat layak untuk digunakan dalam menentukan siswa dengan peningkatan hasil belajar paling baik di Sekolah Dasar Islam Al-Fauzien

\section{E. DAFTAR PUSTAKA}

[1] Arikunto, Suharsimi. (2009). Manajemen Penelitian, edisi Revisi. Jakarta: Rineka Cipta

[2] Arikunto, Suharsimi. (2010). Prosedur Penelitian Suatu Pendekatan Praktik. Jakarta: PT. Rineka Cipta.

[3] Basariyadi, Abdi. (2018). Pengertian SDM dan MSDM. diambil dari: https://majalahpendidikan.com/sumber-daya-manusia-sdm-msdm-pengertian-fungsi-dancontoh/ [diakses tanggal 9 agustus 2018]

[4] DeLone, McLean, RS., Model Kesuksesan Sistem Teknologi Informasi, Yogyakarta, 2003

[5] Filus, Teo. (2017) Pengenalan Bahasa Pemrograman C\#. diambil dari: https://www.codepolitan.com/pengenalan-bahasa-pemrograman-c-587effa1cb95b [diakses tanggal 5 Oktober 2019]

[6] Hamalik, Oemar. (2011). Proses Belajar Mengajar. Jakarta: PT. Bumi Aksara

[7] Huda, Fatkhan Amirul (2017) Pengertian Sistem Pendukung Keputusan (SPK). diambil dari: http://fatkhan.web.id/pengertian-sistem-pendukung-keputusan-spk/ [diakses tanggal 7 Agustus 2019]

[8] Kusumadewi, Sri, 2006, Fuzzy Multi-Atrribute Decision Making (Fuzzy MADM). Yogyakarta: Graha Ilmu.

[9] Kusumah, Wijaya dan Dwitagama Dedi. 2011. Mengenal Penelitian Tindakan Kelas. Jakarta: PT Indeks

[10] Lubis, Derman J., and Nur M. Fadil. "Penerapan Metode SAW (Simple Additive Weighting) untuk Menentukan Siswa Bermasalah di SMK Taruna Terpadu 2 Bogor." Teknois, vol. 10, no. 1, 4 May. 2020, pp. 35-44, doi:10.36350/jbs.v10i1.76.

[11] Pressman, RS. (2012). Rekayasa Perangkat Lunak. Yogyakarta: Andi.

[12] Putra, RB. Nuriana Alim. (2016). Sistem Pendukung Keputusan. diambil dari: https://www.academia.edu/24491699/Sistem_Pendukung_Keputusan [diakses tanggal 8 Agustus 2019]

[13] Raharjo, Sahid. (2013). Angket sebagai Teknik Pengumpulan Data. diambil dari: https://www.konsistensi.com/2013/04/angket-sebagai-teknik-pengumpulan-data.html [diakses tanggal 23 Agustus 2019]

[14] Sekaran, Uma. 2011. Metode Penelitian untuk Bisnis. Jakarta: Salemba Empat.

[15] Slameto. (2010). Belajar dan Faktor-Faktor yang Mempengaruhi. Jakarta: PT. Rineka Cipta.

[16] Sugeng (2016) Penelitian Research and Development (R\&D) - Pengertian, Karakteristik dan Langkah. diambil dari: http://ayo-nambah-ilmu.blogspot.com/2016/06/penelitianresearch-and-development-r.html [diakses tanggal 10 agustus 2019]

[17] Sugiyono. (2009). Metode Penelitian Pendidikan Pendekatan Kuantitatif, Kualitatif, dan R \& D. Bandung: Alfabeta.

[18] Utari, Lis, and Ria Agustriani. "Penerapan Metode Simple Additive Weighting untuk Merekomendasikan Penentuan Supplier Bahan Baku Kertas." Teknois, vol. 9, no. 1, 16 May. 2019, pp. 43-52, doi:10.36350/jbs.v9i1.3. 